\title{
Cardiac abnormalities in children with thalassemia major: correlation of echocardiographic parameters with serum ferritin levels
}

\section{Niranjan Hunsanahalli Shivanna*, Rajashekhara Murthy G. R Halli Ramachamdrappa, Ambica, Govindraju Munirathnam}

Department of Pediatrics, Indira Gandhi Institute of Child Health, Bangalore, Karnataka, India

Received: 30 November 2015

Accepted: 12 December 2015

\section{* Correspondence:}

Dr. Niranjan Hunsanahalli Shivanna,

E-mail: drniranjan_hs@yahoo.com

Copyright: (C) the author(s), publisher and licensee Medip Academy. This is an open-access article distributed under the terms of the Creative Commons Attribution Non-Commercial License, which permits unrestricted non-commercial use, distribution, and reproduction in any medium, provided the original work is properly cited.

\section{ABSTRACT}

Background: Thalassemias are a group of inherited disorders of haemoglobin synthesis, with significant morbidity and mortality. The leading cause of death in transfused thalassemia major children is myocardial haemosiderosis. Echocardiographic estimation of left ventricular function may reveal abnormalities before there is any clinical evidence of cardiac disease. The aim of the study was to determine the magnitude and nature of cardiac involvement in children with thalassemia major with respect to various serum ferritin levels.

Methods: A prospective study was done on 30 cases of Thalassemia major attending our tertiary referral centre for a period of two yrs. The relationship of blood transfusion and serum ferritin with the parameters PWT-d, PWT-s, LViedd, LViesd, septal thickness, E/A and ES were studied.

Results: Out of 30 patients studied, mean age was 4.02 yrs, mean number of transfusions was 28.97 and mean serum ferritin level was 1475. Mean serum ferritin levels of the patients receiving transfusions were estimated in various groups, ferritin levels were higher $(2610 \pm 115.33)$ in patients who had received more than 50 transfusions. 3 of our patients had features of left ventricular hypertrophy in ECG, rest were normal and none of them had evidence of cardiac arrhythmia. Echo parameters were compared; an increase in LViesd was noted in cases when compared to controls which was statistically significant (0.006).

Conclusions: Persistent ferritin levels greater than $2500 \mathrm{mcg} / \mathrm{ml}$ and assessment of annual blood requirement can assist in prediction of development of cardiac disease. Thus, regular monitoring for cardiac dysfunction and arrhythmias with annual echocardiogram and ECG is extremely important.

Keywords: Thalassemia major, Echocardiography, Left ventricular hypertrophy, Serum ferritin

\section{INTRODUCTION}

Thalassemias are a group of inherited disorders of haemoglobin synthesis, resulting from a defective synthesis of one of the two globin chains alpha or beta Thalassemia major is a homozygous state, which results from defective beta chain synthesis in haemoglobin. The leading cause of death in transfused thalassemia major children is myocardial haemosiderosis. ${ }^{1}$ In thalassemic children long term transfusion therapy, haemolysis and increased intestinal absorption of iron results in systemic iron overload. After a year of regular transfusions, iron starts accumulating in parenchymal tissues where it can cause progressive toxic damage. Most clinical manifestations of iron overload, which includes progressive dysfunction of the heart, liver and endocrine organs appear during the second decade of life.

Myocardial iron deposition causes cardiac hypertrophy and dilatation and degeneration of myocardial fibres. The unbound iron generates toxic oxygen free radicals resulting in further injury to the myocytes. Patients develop conductive disturbances and progressive heart failure. ${ }^{2}$ Regular monitoring for cardiac dysfunction and 
arrhythmias with annual echocardiogram and ECG is extremely important. Persistent ferritin levels > 2500 $\mu \mathrm{g} / \mathrm{L}$ and assessment of annual blood requirement can assist in prediction development of cardiac disease. ${ }^{2}$ Unless intensive chelation is started in the first decade of life, myocardial haemosiderosis is inevitable in the second decade. The first ECG abnormalities to be noted include a prolonged PR interval, first degree heart block and premature atrial contractions. The appearance of ST segment depression and ventricular ectopic beats constitute ominous indicators of myocardial damage. ${ }^{3}$ Echocardiographic estimation of left ventricular function may reveal abnormalities before there is any clinical evidence of cardiac disease. Though the liver biopsy has always been considered to be the gold standard for estimating the iron overload. Serum ferritin levels can still be used, with a threshold level of approximately $2500 \mu \mathrm{g} / \mathrm{L}^{2}$. This study was conducted to determine the magnitude and nature of cardiac involvement in children with thalassemia major with respect to various serum ferritin levels.

\section{METHODS}

The study population consisted of 30 patients with thalassemia major aged 1-12 years with a mean age of 4.02 years attending thalassemia clinic at Indira Gandhi institute of child health. A case control study consisting of 30 children was taken up to study the relationship of blood transfusion and serum ferritin with the parameters PWT-d, PWT-s, LViedd, LViesd, septal thickness, E/A and ES.

\section{Inclusion criteria}

Children with thalassemia major, absence of coexisting cardiac disease, frequency of blood transfusion ranging from 1 week to one month.

Children of either sex with thalassemia major diagnosed on clinical, haematological and biochemical criteria were enrolled in the study. All those children who fulfilled the inclusion criteria were subjected to detailed evaluation of history including the age of diagnosis and first transfusion, frequency of blood transfusion, number of transfusions received so far and iron chelation therapy. They were subjected to detailed cardiovascular examination to assess the evidence of signs of congestive cardiac failure like tachycardia, pedal edema and hepatomegaly. Then they were subjected to a 12 lead scalar ECG. The following parameters were studied, pericardium, valves, $\mathrm{M}$ mode and Doppler echocardiogram. All these children underwent serum ferritin estimation at the time of cardiac evaluation. The controls were age and sex matched children free of any cardiac illness. Statistical analysis was done using student $\mathrm{t}$ test of significance and Mann Whitney U test.

\section{RESULTS}

Out of 30 patients studied, majority were between the age group 1-4 yrs (73.3\%), 17 were males $(56.6 \%)$ and 13 were females $(43.3 \%)$, mean age was 4.02 yrs, mean number of transfusions was 28.97 and mean serum ferritin level was 1475 .Majority of patients were diagnosed at less than 6 months of age(47\%), 6 months to 2 yrs $(33 \%)$ and $>2$ yrs of age $(20 \%)$.

All the 30 patients were on regular transfusions, only two received more than 100 transfusions, majority of the patients received 1 to 55 transfusions.5 out of 30 (16\%) were on chelation therapy. $46.7 \%$ (14)patients had serum ferritin level 400 to $1200 \mathrm{ng} / \mathrm{ml}, 30 \%$ (9) had $1201-2000$ $\mathrm{ng} / \mathrm{ml}$ and $23.3 \%$ (7) had more than $2000 \mathrm{ng} / \mathrm{ml}$.Mean serum ferritin levels of the patients receiving transfusions were estimated in various groups, ferritin levels were higher $(2610 \pm 115.33)$ in patients who had received more than 50 transfusions. 3 of our patients had features of left ventricular hypertrophy in ECG ,rest were normal and none of them had evidence of cardiac arrhythmia.

Table 1: Echocardiographic variables (Mean \pm SD) in cases and controls.

\begin{tabular}{|c|c|c|c|c|}
\hline \multirow[t]{2}{*}{ Parameters } & \multicolumn{2}{|c|}{ Mean \pm SD } & \multirow{2}{*}{$\begin{array}{l}\text { Student } \\
\mathbf{t}\end{array}$} & \multirow{2}{*}{$\begin{array}{l}\mathbf{P} \\
\text { value }\end{array}$} \\
\hline & Control & Case & & \\
\hline $\begin{array}{l}\text { Posterior wall } \\
\text { thickness in } \\
\text { diastole (mm) }\end{array}$ & $\begin{array}{l}4.85 \pm \\
0.78\end{array}$ & $\begin{array}{l}5.54 \\
\pm 1.36\end{array}$ & 2.393 & $0.020^{*}$ \\
\hline $\begin{array}{l}\text { Posterior wall } \\
\text { thickness in } \\
\text { systole }(\mathrm{mm})\end{array}$ & $\begin{array}{l}5.25 \pm \\
0.91\end{array}$ & $\begin{array}{l}5.92 \\
\pm 1.51\end{array}$ & 2.100 & $0.040^{*}$ \\
\hline $\begin{array}{l}\text { Left } \\
\text { ventricular } \\
\text { internal end } \\
\text { diastolic } \\
\text { diameter (mm) }\end{array}$ & $\begin{array}{l}27.33 \pm \\
5.85\end{array}$ & $\begin{array}{l}32.55 \\
\pm 9.13\end{array}$ & 2.637 & $0.011^{*}$ \\
\hline $\begin{array}{l}\text { Left } \\
\text { ventricular } \\
\text { internal end } \\
\text { systolic } \\
\text { diameter }(\mathrm{mm})\end{array}$ & $\begin{array}{l}18.33 \pm \\
4.60\end{array}$ & $\begin{array}{l}23.47 \\
\pm 8.76\end{array}$ & 2.844 & $0.006^{* *}$ \\
\hline $\begin{array}{l}\text { Septal } \\
\text { thickness } \\
(\mathrm{mm})\end{array}$ & $\begin{array}{l}4.79 \pm \\
0.77\end{array}$ & $\begin{array}{l}5.69 \\
\pm 1.36\end{array}$ & 2.442 & $0.018^{*}$ \\
\hline $\mathrm{E} / \mathrm{A}$ & $\begin{array}{l}2.54 \pm \\
0.11 \\
\end{array}$ & $\begin{array}{l}2.22 \\
\pm 0.39\end{array}$ & 4.374 & $\begin{array}{l}\mathrm{P} \\
<0.01^{* *}\end{array}$ \\
\hline $\begin{array}{l}\text { Ejection } \\
\text { fraction }(\%)\end{array}$ & $\begin{array}{l}67.67 \pm \\
3.88\end{array}$ & $\begin{array}{l}60.83 \\
\pm 5.26\end{array}$ & - & $\begin{array}{l}\mathrm{P} \\
<0.01^{* *}\end{array}$ \\
\hline
\end{tabular}

*Statistical significance at $5 \%$; ** Statistical significance at $1 \%$

Echo parameters were compared; an increase in LViesd was noted in cases when compared to controls. This was highly statistically significant, with a $\mathrm{p}$ value of 0.006 . Both E/A and EF were reduced in cases with statistical significance. PWT-d, PWT-s, LViedd and ST were also increased with statistical significance. 
As mentioned in table 1, the mean and the SD of posterior wall thickness in diastole and posterior wall thickness in systole were $5.54 \pm 1.36$ and $5.92 \pm 1.51$ respectively as compared to $4.85 \pm 0.78$ and $5.25 \pm 0.91$ in controls. The $\mathrm{p}$ values were 0.020 and 0.040 which is statistically significant.
The mean and the SD of left ventricular internal end diastolic diameter and left ventricular internal end systolic diameter were $32.55 \pm 9.13$ and $23.47 \pm 8.76$ respectively as compared to $27.33 \pm 5.85$ and $18.33 \pm 4.60$ in controls. The $\mathrm{p}$ value is statistically significant for left ventricular internal end diastolic diameter (0.011) and highly statistically significant for left ventricular internal end systolic diameter (0.006).

Table 2: Association of various echo parameters with serum ferritin.

\begin{tabular}{|llllllll|}
\hline $\begin{array}{l}\text { Serum Ferritin } \\
\text { ( No of cases) }\end{array}$ & $\begin{array}{l}\text { Mean values of the parameters (SD) } \\
(\mathrm{mm})\end{array}$ & $\begin{array}{l}\text { PWT-s } \\
(\mathrm{mm})\end{array}$ & $\begin{array}{l}\text { LViedd } \\
(\mathrm{mm})\end{array}$ & $\begin{array}{l}\text { Lviesd } \\
(\mathrm{mm})\end{array}$ & ST $(\mathrm{mm})$ & E/A & EF(\%) \\
\hline $400-1200(14)$ & $\begin{array}{l}4.74 \\
(0.76)\end{array}$ & $\begin{array}{l}4.88 \\
(0.70)\end{array}$ & $\begin{array}{l}27.07 \\
(6.88)\end{array}$ & $\begin{array}{l}18.86 \\
(6.41)\end{array}$ & $4.90(0.54)$ & $2.30(0.40)$ & $63.57(4.97)$ \\
\hline $1201-2009(9)$ & $\begin{array}{l}5.94 \\
(1.51)\end{array}$ & $\begin{array}{l}6.20 \\
(1.50)\end{array}$ & $\begin{array}{l}33.40 \\
(8.57)\end{array}$ & $\begin{array}{l}24.97 \\
(8.99)\end{array}$ & $5.77(1.61)$ & $2.17(0.35)$ & $59.44(4.64)$ \\
\hline$>2000(7)$ & $\begin{array}{l}6.63 \\
(1.23)\end{array}$ & $\begin{array}{l}7.66 \\
(0.91)\end{array}$ & $\begin{array}{l}42.43 \\
(4.16)\end{array}$ & $\begin{array}{l}30.79 \\
(7.68)\end{array}$ & $7.19(0.57)$ & $2.11(0.45)$ & $57.14(3.93)$ \\
\hline Correlation & $0.624^{* *}$ & $0.773^{* *}$ & $0.727^{* *}$ & $0.616^{* *}$ & $0.682^{* *}$ & -0.187 & $-0.551^{* *}$ \\
\hline
\end{tabular}

The mean septal thickness in cases and controls were $5.69 \pm 1.36$ and $4.79 \pm 0.77$ respectively, which is statistically significant with a $\mathrm{p}$ value of 0.018 .E/A and ejection fraction were $2.22 \pm 0.39$ and $60.83 \pm 5.26$ respectively as compared to $2.54 \pm 0.11$ and $67.67 \pm 3.88$ and both are highly statistically significant. The pericardium and the valves were normal in all 30 patients. The relationship between serum ferritin and PWT is established with Pearson correlation coefficient $r$ is 0.624 $(p<0.01)$ and 0.773 for diastole and systole respectively, magnitude of relationship is higher for the diastole. LViedd and LViesd are positively correlated with serum ferritin levels, magnitude of relationship is higher for the LViedd $(\mathrm{r}=0.727)$. Septal thickness is positively related with $\mathrm{r}$ value of 0.682 whereas $\mathrm{E} / \mathrm{A}$ is negatively related with $\mathrm{r}=-0.187$.

Echo parameters were compared with number of transfusions. PWT-s, LViedd, LViesd and ST showed an increase with increasing number of transfusions and EF showed a decrease. These were statistically significant, PWT-d is also increasing with increasing number of transfusions with a near statistical significance of 0.355.E/A was found to be negatively related but there was no statistical significance. Increase in septal thickness was noted with increasing number of transfusions with a correlation coefficient of 0.602 which is highly statistically significant.

Echo parameters were compared with levels of serum ferritin at various ranges. PWT-d, PWT-s, LViedd, LViesd, ST were positively related and EF negatively related with increase in serum ferritin levels. These were highly statistically significant/A was negatively related with increase in serum ferritin level as mentioned in table 2.

\section{DISCUSSION}

Study was done with objective of assessing the cardiac status of multitransfused thalassemic patients by echocardiography. Mean age in the present study was 4.02 \pm 3.37 which is comparable to Hala Agha et al and Kremastino et al. ${ }^{4,5}$ In our study it was found that for every transfusion, there was an average increase of serum Ferritin by $18.727 \mathrm{ng} / \mathrm{ml}$ with an accuracy of $60 \%$.

Various studies have been done to understand the cardiac involvement in thalassemia patients. 6 out of 197 in a study by Athanasios et al and 7 out of 24 patients in a study by Leon et al had features of CCF. ${ }^{6,7}$ In our study one of the 30 patients had clinical evidence of cardiac failure, which is comparable to the study by Hala Agha et al who studied 32 children none of them had clinical evidence of cardiac failure. ${ }^{4}$ ECG was abnormal in 3 $(10 \%)$ of our patients, only abnormality detected being left ventricular hypertrophy. Echocardiography had been used as a non-invasive tool for assessment of cardiac involvement in thalassemia major patients. Both PWT-d and PWT-s increase with increasing number of transfusions with a near statistical significance of 0.355 for PWT-d and high statistical significance of 0.554 for PWT-s. This is in comparable to KC Lau et al who had done follow up study for $5 \mathrm{yrs}$ and showed that there was progressive increase in end diastolic wall thickness during the course of time without the corresponding increase in systolic wall thickness indicating that diastolic abnormality occurred earlier. ${ }^{8}$ 
Ejection fraction is the single most single index of left ventricular function because it correlates with clinical outcome. We have found that the ejection fraction was significantly lower than control group. This is comparable to Lau $\mathrm{KC}$ et al, L Hui et al and G Bosi et al. ${ }^{8-10}$ The ratio of early to late transmitral flow velocity (E/A) was reduced when compared to controls which suggest impaired relaxation of left ventricle during diastole .

The pericardium and valves were normal in all our patients whereas Athanasios have found significant pericardial thickening and valvular abnormalities in 38 and 53 respectively out of 110 patients. $^{6}$

We have also studied the correlation between the number of transfusions received, serum ferritin levels and echocardiographic parameters. In our study we have observed echocardiographic abnormalities in patients who had received $<50$ transfusions, but according to study by Nathan et al there was correlation between number of units transfused and echocardiographic abnormalities only when they receive more than 100 transfusions. ${ }^{11}$

The studies of correlation between serum ferritin levels and echocardiographic abnormalities have shown varying findings. In our study there is significant correlation between serum ferritin and all the parameters whereas according to yapark $\mathrm{j}$ et al, there was no significant correlation between ferritin levels and the echocardiographic abnormalities' Bosi et al found weak but significant correlation between left ventricular ejection fraction and serum ferritin concentration. ${ }^{10,12}$

\section{CONCLUSION}

Most patients with thalassemia major are severely anaemic and require frequent transfusions. The aim of the therapy is to maintain the haemoglobin at the safe level. Thus a repeated transfusion coupled with increased gastrointestinal absorption of iron results in iron overload. Iron is deposited in various organs including heart. Cardiac involvement occurs when there is myocardial deposition of iron. Regular monitoring for cardiac dysfunction and arrhythmias with annual echocardiogram and ECG is extremely important. Persistent ferritin levels greater than $2500 \mathrm{mcg} / \mathrm{ml}$ and assessment of annual blood requirement can assist in prediction of development of cardiac disease. So it is possible with serial echocardiographic evaluation to find the cardiac status before the clinical symptoms of cardiac failure develop and appropriate measures like chelation therapy can be instituted.

\section{ACKNOWLEDGEMENTS}

We wish to thank our director and all staff of Indira Gandhi Institute of child health Bangalore for their support in the study. We wish to thank all the children and parents/caregivers of the Thalassemia children of Indira Gandhi Institute of child health Bangalore for their cooperation in the study.

\section{Funding: No funding sources}

Conflict of interest: None declared

Ethical approval: The study was approved by the Institutional Ethics Committee

\section{REFERENCES}

1. Lukens NJ. Wintrobes clin Haematology.The thalassemias and related disorders. $10^{\text {th }}$ ed. 1405 1448.

2. Louise L, Sylvia TS. Thalassemia: Current approach to an old disease. Paed clin North America. 2002;49:1165-87.

3. Benz EJ, Patricia J. Thalassemia syndromes. In: Miller RD, Baechum RL. Textbook of Haematology $7^{\text {th }}$ ed. 460-499.

4. Agha H, Mansour I. Echo cardiographic features in patients with thalassemia major: Egypt Heart J. 9(4):475-481.

5. Kremastinos DT, Tsiapras DP. Left ventricular filling pattern in $\beta$-thalassemia major-A Doppler echocardiographic study. EurH J. 1993;14(3):351-7.

6. Athanasios A, Farmakis D. Cardiac involvement in thalassemia intermedia, a multicenter study; Blood. 2001;97(11):3411-6.

7. Leon MB, Borer JS, Green MV, Benz EJ. Detection of early cardiac dysfunction in patients with thalassemia major; NewEng J Med. 1979;301:11438 .

8. Lau KC, Hui PW. Left ventricular function in $\beta$ thalassemia major Archives of Disease in childhood. 1989,64:1046-51.

9. Hui L, Leung MP. Early detection of left ventricular dysfunction in patients with $\beta$ thalassemia major by dobutamine stress echocardiography: Heart. 2003;89:669-70.

10. Bossi G, Crepaz R. Left ventricular remodelling, and systolic and diastolic function in young adults with $\beta$ thalassemia major: A Doppler echocardiographic assessment and correlation with haematologic data; Heart. 2003;89:762-6.

11. Nathan DG, Gunn RB. Thalassemia, Nathan and Oski's Haematology of Infancy and Childhood $6^{\text {th }}$ ed. 2009;1:873-900.

12. Yaprak I, Aksit S. Left ventricular diastolic abnormalities in children with $\beta$ thalassemis major;A Doppler echocardiographic study. Turk J Pediatr. 1998;40(2):201-9.

Cite this article as: Shivanna NH, Rajashekhara Murthy GR, Ambica, Munirathnam G. Cardiac abnormalities in children with thalassemia major: correlation of echocardiographic parameters with serum ferritin levels. Int J Contemp Pediatr 2016;3:12-5. 